\title{
Physico-Chemical Characterization and Product Development from Ginger (Zingiber officinalis) Germplasm Available in South Western Region of Bangladesh
}

\author{
Afroza Akhtar ${ }^{1}$, Prosanta Kumar Dash ${ }^{2}$ and Md. Abdul Mannan ${ }^{3}$ \\ '(Student, KCC Women's College (Under Khulna University), Food and Nutrition Department, Khulna, \\ Bangladesh) \\ 2 (Lecturer, Agrotechnology Discipline, Khulna University, Khulna-9208, Bangladesh) \\ 3(Professor, Agrotechnology Discipline, Khulna University, Khulna-9208, Bangladesh)
}

\begin{abstract}
An investigation was carried out to study the physico-chemical characteristics of 10 selected ginger germplasm of South Western region of Bangladesh from August 2012 to January 2013. The experiment was carried out in completely randomized design. The physico-chemical characters of 10 germplasms of ginger species were studied. There was significant variation among the germplasms in relation to rhizome characteristics and organoleptic evaluation. Better performance of ginger was found in germplasm No. 1 in respect of total rhizome weight, rhizome width, rhizome height, pulp weight, pulp thickness, skin thickness and percents of edible part. Ginger germplasm No. 7 gave better value in respect of $p H$ (6.71) and vitamin C (5.70) content of rhizome pulp. The total soluble solids found higher (6.67\%) in germplasm No. 1 and titratable acidity $(5.68 \%)$ in germplasm No. 2. Carotenoids $(0.200 \mathrm{mg} / 100 \mathrm{~g})$ found maximum in germplasm No. 10 . Germplasm No. 3 and 2 was better in respect of anthocyanin $(0.17 \mathrm{mg} / 100 \mathrm{gm})$ and flavonoids $(11.27 \mathrm{gm})$ content of ginger pulp. In case of product development from different ginger, sauce was successfully prepared by using $400 \mathrm{~g}$ sugar containing treatment consisting 300-500 $\mathrm{g}$ of sugar with $100 \mathrm{~g}$ variation of sugar in three treatments without changing other ingredient. Ginger pakora was successfully prepared by using $25 \mathrm{~g}$ flour containing treatment consisting $15-25 \mathrm{~g}$ of flour with $5 \mathrm{~g}$ variation in three treatments without changing other ingredient. All ginger germplasms are not available year round in the country. So it is possible to preserve these rhizomes by development of products like sauce, pakora, laddu, nimky etc. to meet the nutritional requirement of people of the country.
\end{abstract}

Keywords: Anthocyanin, Carotenoids, Germplasam, Rhizome and Titratable acidity.

\section{Introduction}

Ginger or ginger root is the rhizome of the plant Zingiber officinalis, consumed as a delicacy, medicine, or spice (Schar, 2006). Ginger comes from the family of Zingiberaceae. The name comes from the ancient word singabera, where it is originated from Greek and Arabic words meaning"shaped like a cone" (Foster, 2010). Ginger is a herb used for spices and as herbal medicine. Ginger can be used fresh, dried and powdered, or as a juice or oil (Lambson, 2010). Even though we call it "ginger root," we are really talking about the rhizome (underground stem) where the plant stores its food supply (Barker, 2010). Ginger is basically a swollen stem. The rhizome ginger looks like deer antlers, and can grow up to one meter in length, the rhizomes (also known as the roots) grow underground, deep beneath the soil (Drori, 2005). The ginger plant has shooting runners of the central plant. The runners which are really the growing tips are used in medicine, tea, drinks, etc. They are collected before the buds come out of the surface of the soil (Schar, 2006). The rhizome is thick, tangled and light to dark beige in color. The stem often extends as much as 1 foot above the ground (Sidhe, 2010).

Ginger is best grown in late winter and early spring because of tropic weather at this time. The best time to harvest ginger is any time after the leaves have died down. Usually it takes eight to ten months to get to that point (Bradtke, 2010). In the winter a ginger plant begins its life cycle in early spring. In late spring or early summer, the leaves send food to the rhizome to help it create the buds that grow into new, self-sufficient plants (Kelly, 2010). Ginger is commonly used as a commercial crop. Fifty percent of worldwide ginger is produced in India, while the best quality of ginger comes from Jamaica (Scheper, 2010). Preliminary research indicates that nine compounds found in ginger may bind to human serotonin receptors which may influence gastrointestinal function In a 2010 study, daily consumption of ginger was shown to help ease muscle pain associated with exercise by $25 \%$ (Nievergelt et al., 2010). According to the USDA Nutrient Data Laboratory, a $100 \mathrm{~g}$ serving of raw ginger root contains 80 calories and $17.77 \mathrm{~g}$ of carbohydrates, $2 \mathrm{~g}$ of which are fiber. It also provides 10 minerals, such as calcium, magnesium and phosphorus, 12 vitamins, such as vitamin $\mathrm{C}$ and choline, and 18 amino acids. Fiber is essential for digestive health and help to promote regular bowel movements. Both calcium 
and vitamin $\mathrm{C}$ are vital for healthy bones and teeth, while magnesium helps to strengthen muscle tone and to sustain a healthy heart.

Zingiber officinalis is one of these traditional folk medicinal plants that have been used for over 2000 years by Polynesians for treating diabetes, high blood pressure, cancer, fitness and many other illnesses (Tepe et al., 2006).Zingiber officinalis contains a number of antioxidants such as beta-carotene, ascorbic acid, terpenoids, alkaloids, and polyphenols such as flavonoids, flavones glycosides, rutin, etc. (Aruoma et al., 1997). Ginger has been used as a spice and as natural additives for more than 2000 years (Bartley and Jacobs, 2000). Also, ginger has many medicinal properties. Studies have shown that, the long term dietary intake of ginger has hypoglycaemic and hypolipidaemic effect (Ahmed and Sharma, 1997). In traditional Chinese and Indian medicine, ginger has been used to treat a wide range of ailments including stomach aches, diarrhea, nausea, asthma, respiratory disorders (Grzanna et al., 2005).

Zingiber officinalis is the most important of all the spices obtained from the underground plant part. It was also one of the first oriental spices to be grown to the Europeans. But now it is found to grow extensively in the tropical and subtropical regions of the world particularly in Bangladesh, India, Taiwan, Jamaica, Africa, Mexico, China and Japan. It is a household remedy for dyspepsia, flatulence, colic and diarrhea. Ginger rhizomes contain both aromatic and pungent compounds. Ginger contains from 0.25 to $3 \%$ of volatile oil of light yellow color. The major pungent compounds found in ginger are the gingerols. It is one of the most widely used spices and has been used in traditional oriental medicines for centuries. Its extract and major pungent compounds have been shown to exhibit a variety of biological activities (Wei et al., 2005). The oleoresin from rhizome of ginger contains pungent ingredients including gingerol, shogaol and zingerone (Surh et al., 1998). Ginger's active components have been reported to exhibit cancer-preventive activity in several experimental carcinogenesis models including skin carcinogenesis (Murillo et al., 2008).

Rhizome of ginger has been used as a medicine in Chinese, Indian and Arabic herbal traditions since ancient times as carminative or antiflatulent, diaphoretic, antispasmodic, expectorant, peripheral circulatory stimulant, astringent, appetite stimulant, anti-inflammatory agent, diuretic and digestive aid etc. (Kizhakkayil and Sasikumar, 2011). About 50 cultivars in addition to seven improved varieties have been reported in India (Sasikumar et al., 1999). Chemical investigation carried out in the past showed that ginger essential oil is mainly composed of zingibe-rene, $\alpha$-curcumene, $\beta$-sesquiphellandrene, citral and campheneetc; and these compounds are characteristic for geographical and varietal properties of ginger (Singh et al., 2008). Chinese dried ginger is exported as whole peeled with two grades, and sliced unpeeled. It is whiter than the Indian ginger, tends to be more fibrous and bitterer. (ASTA, 2002)

Hence, the present study was under taken to fulfil the following objectives:

i) To study the pattern of physico-chemical properties of some selected ginger germplasm.

ii) To develop the product from ginger to meet nutritional requirement of people of the country for increasing availability during out of season.

\section{Materials And Methods}

Ginger is herb used for spices as well as herbal medicine. Many research works have been done in different part of the world to study the physic-chemical and product development from ginger. The experiment on physico-chemical characteristics and product development from ginger and turmeric was carried out during the period from August, 2012 to January, 2013. In the study 10 ginger germplasms were studied which were collected randomly from south western region of Bangladesh. The collected ginger germplasm were brought to the Molecular Horticulture Laboratory of the Agrotechnology Discipline of Khulna University, Khulna. In the laboratory, the ginger was studied to determine their physico-chemical characteristics and was used to make some products.

\section{Physico-chemical characteristics of ginger germplasm of the south western region of Bangladesh}

\subsection{Experimental Design and Analysis}

The experiment was laid out in Completely Randomized Design (CRD) with three replications. After collection of some ginger and turmeric they kept in ambient temperature for the study of physico-chemical characteristics. The collected data from experiment was statistically analyzed by Analysis of Variance (ANOVA). Duncan's New Multiple Range Test (DMRT) was used to compare the means of different parameters and the means were calculated by using "MSTATC" programme in computer.

\subsection{Experimental Materials}

Ten germplasms of mature ginger germplasm were selected as the experimental materials for the investigation. These ginger was collected from different place of south western region of Bangladesh. 


\subsection{Methods of Studying Parameters} were studied.

By using the following methods physical and chemical parameters of the collected ginger germplasms

\subsubsection{Physical Parameter}

\subsubsection{Weight of ginger and turmeric}

The weight of ginger was measured by an electric balance. At first, the balance was adjusted to zero mark. The ginger was cleaned and weighted by keeping the ginger on the chamber of the balance. Then the reading was taken in gram $(\mathrm{g})$.

\subsubsection{Size of ginger}

Length, width and depth of the ginger were estimated to determine the ginger size by a slide calliper. The values of these parameters were taken in centimetre $(\mathrm{cm})$.

\subsubsection{Weight of skin of ginger}

The weight of skin of ginger was measured by an electric balance. At first, the balance was adjusted to zero mark. The skin of the ginger was separated by using a sharp knife from the ginger pulp. Then the weight of the skin was estimated by keeping it in the chamber of balance and the reading was taken in gram (g).

\subsubsection{Weight of edible portion of ginger}

The weight of edible portion of ginger was measured by an electric balance. At first, the balance was adjusted to zero mark. After removing the skin from ginger the remaining edible portion (pulp) was estimated by keeping it in the chamber of balance and the reading was taken in gram (g).

\subsubsection{Weight of non-edible portion of ginger}

Weight of non-edible portion of the ginger was measured by subtracting the weight of edible portion from the total weight of ginger. This weight was measured in gram (g).

\subsubsection{Percentage of edible portion of ginger}

The percentage of edible portion of ginger (pulp) was calculated by the following formula:

$$
\text { Percentage of edible portion }=\frac{\text { Weight of edible parts }}{\text { Weight of whole rhizome }} \times 100
$$

\subsubsection{Percentage of nonedible portion of ginger}

The percentage of nonedible (skin) portion of ginger was calculated by the following formula:

Percentage of non-edible portion $=\frac{\text { Weight of non edible parts }}{\text { Weight of whole rhizome }} \times 100$

\subsubsection{Chemical characteristics}

The methods for the estimation of pH, TSS, Titrable acidity, vitamin C, Carotenoids, Anthocyanin and Flavonoids of ginger pulp were followed as described by Mazumdar and Majumdar (2001) and Sainiet al. (2006). The data were analyzed by fresh weight basis.

\subsection{Development of products from ginger}

To develop products from the selected rhizomes, the experiment was laid out considering three replications with three formulations. The formulations for this experiment have been shown in Table 1 and 2 . Sensory evaluation of ginger products were done following the method adopted by Hossain and Siddique (1982). The individual product's quality was found by analysing the following characteristics- (i) colour, (ii) taste, (iii) flavour and (iv) texture and Complete Randomized Design (CRD) was applied for the analysis of experimental data.

In this experiment sauce and pakora were developed from ginger. The ingredients and procedure which were used to develop products are presented below:

\subsubsection{Product name: Ginger pakora}


2.4.1.1 Procedure: There are several stages in the procedure which was used to develop pakora from ginger. These stages are briefly stated below:

2.4.1.2 Selection and washing of rhizomes: Properly matured and fresh ginger were collected and washed thoroughly with fresh water.

2.4.1.3 Slicing of rhizomes: The ginger were weighted and made thin slices by releasing skin. When slicing finished, cut the sliced ginger into small pieces.

Table 1. Ingredients for ginger pakora formulation

\begin{tabular}{|c|l|c|c|c|}
\hline SI. No. & Ingredients & $\mathbf{T}_{\mathbf{1}}$ & $\mathbf{T}_{\mathbf{2}}$ & $\mathbf{T}_{\mathbf{3}}$ \\
\hline 01 & Ginger (g) & 500 & 500 & 500 \\
\hline 02 & Onion & 300 & 300 & 300 \\
\hline 03 & Oil (ml) & 250 & 250 & 250 \\
\hline 04 & Green chilli (g) & 10 & 10 & 10 \\
\hline 05 & Salt (g) & 20 & 20 & 20 \\
\hline 06 & Egg (p) & 3 & 3 & 3 \\
\hline 07 & Flour (g) & 15 & 20 & 25 \\
\hline 08 & Baking powder(g) & 10 & 10 & 10 \\
\hline
\end{tabular}

\subsubsection{Mixing of all ingredients:}

I took ginger pieces, onion, green chilli, in a mixing bowl. Adding salt and mix it well with the mixture. Then slowly added flour and mix. Adding egg (beaten) and baking powder, and mix them well.

\subsubsection{Frying:}

Heating oil in pan to medium flame. When oil is hot, take small amount from the mix, round it and then flatted it lightly and put carefully to the oil. Putting few pieces at a time and fry those till both sides turn to a nice golden brown color.

\subsubsection{Packing:}

After removing pakora from the pan, place on a kitchen tissue to soak extra oil. Pack the crispy pakora after cooling.

\subsubsection{Product name: Ginger sauce}

2.4.2.1 Procedure: There are several stages in the procedure which was used to develop sauce from ginger. These stages are briefly stated below:

2.4.2.2 Selection and washing of rhizomes: Properly matured and fresh ginger were collected and washed thoroughly with fresh water.

2.4.2.3 Slicing and mashing of sliced rhizomes: The ginger were weighted and made thin slices by releasing skin. When slicing finished, the cut pieces were weigh-out and boiled for 8-10monutes.Half boiled materials were drained and let them cool. After cooling mash the boiled ginger.

Table 2. Ingredients for ginger sauce formulation

\begin{tabular}{|c|l|c|c|c|}
\hline Sl. No. & Ingredients & $\mathbf{T}_{\mathbf{1}}$ & $\mathbf{T}_{\mathbf{2}}$ & $\mathbf{T}_{\mathbf{3}}$ \\
\hline 01 & Ginger $(\mathrm{g})$ & 500 & 500 & 500 \\
\hline 02 & Sugar $(\mathrm{g})$ & 300 & 400 & 500 \\
\hline 03 & Mustard oil $(\mathrm{ml})$ & 100 & 100 & 100 \\
\hline 04 & Red chilli $(\mathrm{g})$ & 10 & 10 & 10 \\
\hline 05 & Salt $(\mathrm{g})$ & 20 & 20 & 20 \\
\hline 06 & Vinegar $(\mathrm{ml})$ & 150 & 150 & 150 \\
\hline
\end{tabular}

\subsubsection{Cooking:}

Recommended pure mustard oil $100 \mathrm{ml} / \mathrm{Kg}$ was taken in a fry pan then added red chilli, mustered and the boiled ginger paste. Add some sail and little amount of water. After that sugar was added and it will be cooked till it fully prepared.

\subsubsection{Bottling and pasteurizing:}

The product now poured into the sterilized bottle. Seal the bottles with lids and pasteurized at 85 degee Celsius. The bottles were then kept in a sound place without any disturb to get it cool. Clean the outside of the bottle and sealed with lids.

\subsection{Sensory Evaluation}

The acceptability of the prepared products of ginger and turmeric was evaluated through a taste-testing panel of 9 judges. The taste-testing panel was made for sensory evaluation of ginger products with teachers and students off different disciplines of Khulna University. All the judges were conversant with the factors governing the quality of the products. The products sample of three treatments were placed in white plates to each judges who independently examined considering the characteristics- i) colour ii) taste iii) flavour and iv) 
texture / crispiness of individual products. The panellists recorded their preferential comments in the supplied questionnaire. The results have been presented both in percentage figures and in acceptability scores. Acceptability score was computed according to the scale as followed by Hossain and Siddique (1982).

\section{Results And Discussion}

The research was carried out to study the physico-chemical characteristics and quality of developed products of ginger at the Molecular Horticulture Laboratory of Agrotechnology Discipline, Khulna University, Khulna from August, 2012 to January, 2013. The data have been presented in tables. The results of this experiment are presented and discussed under the following headings.

\subsection{Physical characteristics of ginger}

Data on physical characteristics of ginger are presented in (Table 5). The physical characteristics of ginger are described based on quantitative and qualitative characteristics.

\subsubsection{Quantitative Characters}

\subsubsection{Weight of individual rhizomes}

The rhizome weight was significantly varied among the 10 germplasm (Table 3). The germplasm No. 01 gave the maximum rhizome weight (122.06 g) followed by germplasm No. $03(113.78 \mathrm{~g})$ which was statistically similar to germplasm No. $04(111.38 \mathrm{~g})$ while it was minimum $(20.74 \mathrm{~g})$ in germplasm No. 08 preceded by germplasm No. 09 (23.76 g), No. 06 (27.59 g) and No.07 ( $30.67 \mathrm{~g}$ ) (Table 3). Average rhizome weight of ginger was found $65.61 \mathrm{~g}$.

\subsubsection{Length of individual rhizome}

Significant differences were found among the 10 germplasm in respect of length of rhizome (Appendix I). The longest rhizome $(10.44 \mathrm{~cm})$ was found in germplasm No. 04 which was statistically similar with germplasm No. $02(10.33 \mathrm{~cm})$ and the shortest rhizome $(4.78 \mathrm{~cm})$ was measured from germplasm No. 10 preceded by germplasm No. $08(5.01 \mathrm{~cm})$, No. $03(6.06 \mathrm{~cm})$ and No. $09(6.5 \mathrm{~cm})$ (Table 5). The average length of rhizome was found $7.72 \mathrm{~cm}$ per rhizome.

\subsubsection{Width of individual rhizome}

Significant variation was found in width of rhizome among the 10 germplasm (Table 3). The broadest rhizome $(4.60 \mathrm{~cm})$ was found in germplasm No.01 followed by germplasm No. $04(3.85 \mathrm{~cm})$ which was statistically similar to germplasm No. $03(3.73 \mathrm{~cm})$, germplasm No. $02(3.72 \mathrm{~cm})$ and the narrowest rhizome $(1.59 \mathrm{~cm})$ was measured from germplasm No. 08 preceded by germplasm No. $09(1.82 \mathrm{~cm})$, germplasm No. $06(2.48 \mathrm{~cm})$ and germplasm No. $10(2.54 \mathrm{~cm})$ (Table 3). The average width of rhizome was found $3.07 \mathrm{~cm}$ per rhizome.

\subsection{Rhizome height}

The rhizome height of the ginger was significantly varied among the 10 germplasm (Table 3 ). The germplasm No. 01 gave the maximum rhizome height $(4.45 \mathrm{~g})$ followed by germplasm No. 04 (3.48 g), germplasm No. 03 (3.41) and germplasm No. 02 (3.25) while rhizome height was minimum (1.3 g) in germplasm No. 08 preceded by germplasm No. 09 (1.77 g), No. 06 (1.96 g) and No. 07 (2.30 g) (Table 3). Average rhizome height of ginger was found $2.74 \mathrm{~g}$.

\subsection{Pulp weight}

The pulp weight of the rhizome was significantly varied among the 10 germplasm (Table 3 ). The germplasm No. 01 gave the maximum pulp weight $(111.36 \mathrm{~g})$ followed by germplasm No. $03(101.27 \mathrm{~g})$ and germplasm No. 04 (99.15 g) while pulp weight was minimum $(17.56 \mathrm{~g})$ in germplasm No. 08 which was statistically similar to germplasm No. 09 (21.73 g), No. 06 (22.13 g) and No. 07 (24.06 g) (Table 3). Average pulp weight of ginger was found $57.74 \mathrm{~g}$.

\subsection{Pulp thickness}

The pulp thickness of the rhizome was significantly varied among the 10 germplasm (Table 3 ). The germplasm No. 01 gave the maximum pulp thickness $(4.11 \mathrm{~g}$ ) which was statistically similar to germplasm No. 05 (3.63 g), germplasm No. $04(3.59 \mathrm{~g})$, germplasm No. $02(3.52 \mathrm{~g})$ and germplasm No. 03 (3.42 g), while pulp thickness was minimum $(1.34 \mathrm{~g})$ in germplasm No. 08 preceded by germplasm No. $09(1.67 \mathrm{~g})$, No. $06(2.3 \mathrm{~g})$ and No. 10 $(2.37 \mathrm{~g})$ (Table 3). Average pulp thickness of ginger was found $2.85 \mathrm{~g}$.

\subsection{Skin weight}

The skin weight of the rhizome was significantly varied among the 10 germplasm (Table 3 ). The germplasm No. 05 gave the maximum skin weight $(13.44 \mathrm{~g})$ followed by germplasm No. $03(12.44 \mathrm{~g})$ and germplasm No. 04 (21.02) while skin weight was minimum(2.03 g) in germplasm No. 09 preceded by germplasm No. 08 (3.18 g), No. $10(5.05 \mathrm{~g})$ and No. $06(5.46 \mathrm{~g})$ (Table 3). Average skin weight of ginger was found $7.67 \mathrm{~g}$.

\subsection{Skin thickness}


Non-significant difference was found among the 10 germplasm in respect of skin thickness (Table 3). However, numerically the highest skin thickness $(0.45 \mathrm{~g})$ was observed from germplasm No. 01 and that was the lowest $(0.09 \mathrm{~g})$ was found in germplasm No. 05 (Table 3). Average skin thickness was found $0.22 \mathrm{~g}$ per rhizome.

\subsection{Percentage of edible portion}

Significant variation was found among the 10 germplasm in respect of percentage of edible portion of the rhizome (Table 3). The results showed that the highest percentage of edible portion $(92.28 \%)$ was found germplasm No. 02 followed by germplasm No. 09 (91.45\%), germplasm No. 01 (91.24 \%), and No. 03 (89.03\%). The lowest percentage (78.44\%) was measured from germplasm No. 07 preceded by the germplasm No. $06(80.19 \%)$ and No. $05(82.37 \%)$ (Table 3). The average percentage of edible portion of rhizome was found $86.42 \%$.

\subsection{Percentage of non-edible portion}

The percentage of non-edible portion of ginger was significantly varied among the 10 germplasm (Table 3 ). The highest percentage of non-edible portion $(21.56 \%)$ was found from germplasm No. 07 followed by germplasm No. $06(19.81 \%)$, No. $05(17.31 \%)$, No. $08(15.30 \%)$ and the lowest percentage $(6.95 \%)$ was found from germplasm No. 02 which was statistically similar to germplasm No. 01 (8.38\%) (Table 3). The average percentage of non-edible portion of ginger was found about $13.25 \%$.

Table 3. Physical Characteristics of Ginger (Zingiber officinalis)

\begin{tabular}{|c|c|c|c|c|c|c|c|c|c|c|}
\hline $\begin{array}{l}\text { Germpl } \\
\text { asm No }\end{array}$ & $\begin{array}{c}\text { Rhizo } \\
\text { me } \\
\text { weight } \\
\text { (g) }\end{array}$ & $\begin{array}{c}\begin{array}{c}\text { Lengt } \\
\text { h }\end{array} \\
\text { of } \\
\text { Rhizo } \\
\text { me } \\
\text { (cm) }\end{array}$ & $\begin{array}{c}\text { Width } \\
\text { of } \\
\text { Rhizome } \\
\text { (cm) }\end{array}$ & $\begin{array}{l}\text { Height } \\
\text { (cm) }\end{array}$ & $\begin{array}{c}\text { Pulp } \\
\text { weight } \\
\text { (g) }\end{array}$ & $\begin{array}{l}\text { Pulp } \\
\text { thickness } \\
\text { (cm) }\end{array}$ & $\begin{array}{l}\text { Skin } \\
\text { Weight } \\
\text { (g) }\end{array}$ & $\begin{array}{c}\text { Skin } \\
\text { thicknes } \\
\text { s } \\
(\mathrm{cm})\end{array}$ & $\begin{array}{c}\% \text { of } \\
\text { edible } \\
\text { part }\end{array}$ & $\begin{array}{c}\% \text { of } \\
\text { non } \\
\text { edible } \\
\text { part }\end{array}$ \\
\hline 1 & $\begin{array}{c}122.06 \\
\mathrm{a}\end{array}$ & $8.79 b$ & $4.601 \mathrm{a}$ & $4.449 \mathrm{a}$ & $111.36 \mathrm{a}$ & $4.113 \mathrm{a}$ & $10.227 \mathrm{abcd}$ & $0.453 \mathrm{a}$ & $91.24 \mathrm{ab}$ & $8.38 \mathrm{~d}$ \\
\hline 2 & $89.27 \mathrm{c}$ & $10.33 a$ & $3.718 \mathrm{~b}$ & $3.249 \mathrm{~b}$ & $82.663 \mathrm{c}$ & $3.516 \mathrm{a}$ & $6.217 \mathrm{abcde}$ & $0.203 \mathrm{a}$ & $92.28 \mathrm{a}$ & $6.95 \mathrm{~d}$ \\
\hline 3 & $\begin{array}{c}113.78 \\
\mathrm{~b}\end{array}$ & $6.06 \mathrm{~d}$ & $3.733 b$ & $3.405 \mathrm{~b}$ & $101.27 \mathrm{~b}$ & $3.424 \mathrm{a}$ & $12.437 \mathrm{ab}$ & $0.298 \mathrm{a}$ & $89.03 \mathrm{abc}$ & $10.93 \mathrm{~cd}$ \\
\hline 4 & $\begin{array}{c}111.38 \\
\mathrm{~b}\end{array}$ & $10.44 \mathrm{a}$ & $3.850 \mathrm{~b}$ & $3.479 \mathrm{~b}$ & $99.153 b$ & $3.591 \mathrm{a}$ & $12.017 \mathrm{abc}$ & $0.259 \mathrm{a}$ & $89.03 \mathrm{abc}$ & $10.78 \mathrm{~cd}$ \\
\hline 5 & $77.72 \mathrm{~d}$ & $7.18 \mathrm{c}$ & $3.716 \mathrm{~b}$ & $3.148 \mathrm{bc}$ & $64.043 \mathrm{~d}$ & $3.629 \mathrm{a}$ & $13.437 \mathrm{a}$ & $0.087 \mathrm{a}$ & $82.37 \mathrm{bcd}$ & $\begin{array}{c}17.31 \mathrm{ab} \\
\mathrm{c}\end{array}$ \\
\hline 6 & $27.59 \mathrm{~g}$ & $9.28 \mathrm{~b}$ & $2.479 \mathrm{~cd}$ & $1.962 \mathrm{de}$ & $22.127 f$ & $2.295 \mathrm{bc}$ & $5.463 \mathrm{bcde}$ & $0.184 \mathrm{a}$ & $80.19 \mathrm{~cd}$ & $19.81 \mathrm{ab}$ \\
\hline 7 & $30.67 f$ & $8.78 b$ & $2.654 \mathrm{c}$ & $2.296 \mathrm{~cd}$ & $24.063 \mathrm{f}$ & $2.512 \mathrm{~b}$ & 6.607abcde & $0.142 \mathrm{a}$ & $78.44 d$ & $21.56 \mathrm{a}$ \\
\hline 8 & $20.74 \mathrm{i}$ & $5.01 \mathrm{e}$ & $1.585 \mathrm{e}$ & $1.303 \mathrm{e}$ & $17.563 \mathrm{f}$ & $1.338 \mathrm{~d}$ & $3.108 \mathrm{de}$ & $0.247 \mathrm{a}$ & $84.70 \mathrm{abcd}$ & $\begin{array}{c}15.29 \mathrm{ab} \\
\mathrm{cd}\end{array}$ \\
\hline 9 & $23.75 \mathrm{~h}$ & $6.50 \mathrm{~d}$ & $1.823 \mathrm{de}$ & $1.773 \mathrm{de}$ & $21.727 f$ & $1.673 \mathrm{~cd}$ & $2.030 \mathrm{e}$ & $0.150 \mathrm{a}$ & $91.45 \mathrm{ab}$ & $8.55 \mathrm{~cd}$ \\
\hline 10 & $39.16 \mathrm{e}$ & $4.78 \mathrm{e}$ & $2.544 \mathrm{~cd}$ & $2.311 \mathrm{~cd}$ & $33.470 \mathrm{e}$ & $2.368 \mathrm{bc}$ & 5.050 cde & $0.174 \mathrm{a}$ & $85.48 \mathrm{abcd}$ & $\begin{array}{c}12.89 \mathrm{bc} \\
\mathrm{d}\end{array}$ \\
\hline Average & 65.61 & 7.71 & 3.070 & 2.737 & 57.743 & 2.846 & 7.666 & 0.220 & 86.42 & 13.25 \\
\hline $\begin{array}{c}\text { Level of } \\
\text { significa } \\
\text { nce }\end{array}$ & $* *$ & $* *$ & $* *$ & $* *$ & $* *$ & $* *$ & $* *$ & NS & $* *$ & ** \\
\hline CV (\%) & 1.66 & 3.06 & 10.22 & 13.45 & 5.37 & 11.10 & 36.91 & 69.81 & 4.26 & 25.72 \\
\hline
\end{tabular}

N.B. In a column figures having similar letters do not differ significantly whereas figures having dissimilar letters differ significantly as per DMRT.

\subsubsection{Qualitative Characters}

\subsubsection{Shape of rhizome}

There was remarkable variable among the 10 germplasm in respect of rhizome shape. Most of the rhizomes were irregular in shape

\subsubsection{Colour of Skin}

Variation was also found in case of type of skin colour among the 10 germplasm. Various skin colour was found in different rhizomes viz. deep brown, brown, greenish brown, yellowish brown and whitish brown

\subsection{Chemical characteristics of ginger 3.2.1 pH of Rhizome pulp}


There was a no significant variation among the 10 germplasm in respect of $\mathrm{pH}$ of rhizome pulp (Table 4).However, numerically the highest $\mathrm{pH}$ of rhizome pulp (6.72) was found in germplasm No. 07 was observed from germplasm No. 01 and the lowest $\mathrm{pH}$ content of rhizome pulp (5.23) was found in germplasm No. 08 (Table 4). Average $\mathrm{pH}$ content of rhizome pulp was found 5.79.

\subsubsection{Total soluble solids (Brix \%) of rhizome pulp}

The difference of total soluble solids was significant among the 10 germplasm (Table 4). The highest percentage of TSS (6.67\%) was observed from germplasm No. 01 followed by germplasm No. $08(6.33 \%)$ and No. $09(6.00 \%)$. The lowest percentage of total soluble solids of rhizome pulp $(3.33 \%)$ was observed from germplasm No. 06 preceded by germplasm No. 05 (3.67\%), No. 10 (4.33\%) and No. 07 (4.67\%) (Table 4). Average total soluble solids were found $5.00 \%$. Increase in total soluble solid may be attributed to increase in soluble sugar, soluble pectin, soluble organic acids etc.

\subsubsection{Titratable acidity of rhizome pulp}

The titratable acidity of ginger was varied significantly among the 10 germplasm (Table 4). However, numerically the highest $\mathrm{pH}$ of rhizome pulp (5.68\%) was found in germplasm No. 02 and the lowest (5.23\%) in germplasm No. 04 (Table 4). Average titratable acidity content of rhizome pulp was found $4.76 \%$.

Table 4. Chemical Characteristics of Ginger (Zingiber officinalis)

\begin{tabular}{|c|c|c|c|c|c|c|c|}
\hline $\begin{array}{c}\text { Germpla } \\
\text { sm no. }\end{array}$ & pH & TSS (\%) & $\begin{array}{c}\text { T-acidity } \\
\text { (\%) }\end{array}$ & $\begin{array}{l}\text { Vitamin-c } \\
(\mathrm{mg} / 100 \mathrm{~g})\end{array}$ & $\begin{array}{c}\text { Carotino } \\
\text { ids } \\
(\mathrm{mg} / 100 \mathrm{~g} \\
)\end{array}$ & $\begin{array}{c}\text { Anthocyani } \\
\text { ne } \\
\text { (mg/100g) }\end{array}$ & $\begin{array}{c}\text { Flavonoi } \\
\text { ds } \\
(\mathrm{g} / \mathbf{1 0 0 g})\end{array}$ \\
\hline 1 & $5.883 a$ & $6.667 \mathrm{a}$ & $4.913 \mathrm{a}$ & $3.500 \mathrm{a}$ & $0.154 b c$ & $0.061 \mathrm{de}$ & $10.283 b c$ \\
\hline 2 & $5.687 \mathrm{a}$ & 5.333abcd & $5.683 a$ & $4.260 \mathrm{a}$ & $0.053 \mathrm{ef}$ & $0.065 \mathrm{de}$ & $11.265 \mathrm{a}$ \\
\hline 3 & $5.577 \mathrm{a}$ & 5.00abcde & $4.817 \mathrm{a}$ & $5.070 \mathrm{a}$ & $0.066 \mathrm{e}$ & $0.167 \mathrm{a}$ & $8.597 d$ \\
\hline 4 & $5.600 \mathrm{a}$ & $4.667 \mathrm{bcde}$ & $4.253 \mathrm{a}$ & $4.410 \mathrm{a}$ & $0.066 \mathrm{e}$ & $0.072 \mathrm{cde}$ & $5.595 \mathrm{f}$ \\
\hline 5 & $6.093 a$ & $3.667 \mathrm{de}$ & $4.733 a$ & $3.870 \mathrm{a}$ & $0.035 \mathrm{f}$ & $0.023 \mathrm{f}$ & $5.561 \mathrm{f}$ \\
\hline 6 & $5.567 \mathrm{a}$ & $3.333 \mathrm{e}$ & $4.643 a$ & $4.290 \mathrm{a}$ & $0.132 \mathrm{~cd}$ & $0.053 \mathrm{e}$ & $10.547 b$ \\
\hline 7 & $6.717 a$ & $4.667 \mathrm{bcde}$ & $5.007 \mathrm{a}$ & $5.700 \mathrm{a}$ & $0.122 \mathrm{~d}$ & $0.090 \mathrm{c}$ & $9.953 c$ \\
\hline 8 & $5.233 a$ & $6.333 \mathrm{ab}$ & $4.74 a$ & $4.890 \mathrm{a}$ & $0.164 b$ & $0.125 b$ & $7.847 \mathrm{e}$ \\
\hline 9 & $5.690 \mathrm{a}$ & $6.000 \mathrm{abc}$ & $4.467 \mathrm{a}$ & $4.730 \mathrm{a}$ & $0.116 \mathrm{~d}$ & $0.081 \mathrm{~cd}$ & $8.167 \mathrm{de}$ \\
\hline 10 & $5.880 \mathrm{a}$ & $4.333 \mathrm{cde}$ & $4.327 \mathrm{a}$ & $4.260 \mathrm{a}$ & $0.200 \mathrm{a}$ & $0.144 \mathrm{ab}$ & $7.743 \mathrm{e}$ \\
\hline Average & $5.793 \mathrm{a}$ & 5.000 & $4.758 \mathrm{a}$ & $4.498 \mathrm{a}$ & 0.111 & 0.088 & 8.596 \\
\hline $\begin{array}{l}\text { Level of } \\
\text { significan } \\
\text { ce }\end{array}$ & NS & $* *$ & NS & NS & $* *$ & $* *$ & $* *$ \\
\hline $\mathrm{CV}(\%)$ & 10.98 & 13.66 & 11.10 & 25.98 & 18.03 & 9.80 & 2.61 \\
\hline
\end{tabular}

N.B. In a column figures having similar letters do not differ significantly whereas figures having dissimilar letters differ significantly as per DMRT.

\subsubsection{Vitamin C (ascorbic acid) content of rhizome pulp}

Non-significant difference was found among the 10 germplasm in respect of vitamin $\mathrm{C}$ content of rhizome pulp (Table 4). However, numerically the highest vitamin C $(5.7 \mathrm{mg} / 100 \mathrm{~g}$ ) was observed from germplasm No. 07 and the lowest $(3.87 \mathrm{mg} / 100 \mathrm{~g})$ was found in germplasm No. 05 (Table 4). Average vitamin $\mathrm{C}$ was found $4.5 \mathrm{mg} / 100 \mathrm{~g}$.

\subsubsection{Carotenoids content of rhizome pulp}

Carotenoids content of rhizome pulp showed significant difference among the 10 germplasm (Table 4). The maximum amount of carotenoids content of rhizome pulp $(0.20 \mathrm{mg} / 100 \mathrm{~g})$ was found in germplasm No. 10 followed by germplasm No. $08(0.16 \mathrm{mg} / 100 \mathrm{~g})$, No. $01(0.15 \mathrm{mg} / 100 \mathrm{~g})$, No. $06(0.13 \mathrm{mg} / 100 \mathrm{~g})$ and No. $07(0.12 \mathrm{mg} / 100 \mathrm{~g})$. The minimum amount of carotenoids content $(0.04 \mathrm{mg} / 100 \mathrm{~g})$ was observed from germplasm No. 05 preceded by germplasm. No. $02(0.05 \mathrm{mg} / 100 \mathrm{~g})$ and No. 04 (0.07 mg /100 g) (Table 4). Average carotenoids content was $0.11 \mathrm{mg} / 100 \mathrm{~g}$ of rhizome pulp.

\subsubsection{Anthocyanin content of rhizome pulp}


The difference of anthocyanin content of rhizome pulp was significant among the 10 germplasm (Table 4). The highest amount of anthocyanin of rhizome pulp $(0.17 \mathrm{mg} / 100 \mathrm{~g})$ was observed from germplasm No. 03 followed by germplasm No. $10(0.14 \mathrm{mg} / 100 \mathrm{~g})$, germplasm No. $08(0.13 \mathrm{mg} / 100 \mathrm{~g})$. The least amount of anthocyanin of rhizome pulp $(0.02 \mathrm{mg} / 100 \mathrm{~g})$ was observed from germplasm No. 05 proceeded by germplasm No. $06(0.05 \mathrm{mg} / 100 \mathrm{~g})$, No. $01(0.06 \mathrm{mg} / 100 \mathrm{~g})$ and No. $02(0.07 \mathrm{mg} / 100 \mathrm{~g})$ (Table 4). Average anthocyanin content of rhizome pulp was $0.09 \mathrm{mg} / 100 \mathrm{~g}$.

\subsubsection{Flavonoids content of rhizome pulp}

There was a significant variation among the 10 germplasm in respect of flavonoids content of rhizome pulp (Table 4). The highest flavonoids content of rhizome pulp $(11.27 \mathrm{~g} / 100 \mathrm{~g})$ was found in germplasm No. 02 followed by germplasm No. $06(10.55 \mathrm{~g} / 100 \mathrm{~g})$, No. $01(10.28 \mathrm{~g} / 100 \mathrm{~g})$ and No. $07(9.95 \mathrm{~g} / 100 \mathrm{~g})$. The lowest flavonoids content of rhizome pulp $(5.60 \mathrm{~g} / 100 \mathrm{~g})$ was found in germplasm No. 04 which was statistically similar to germplasm No. $05(5.96 \mathrm{~g} / 100 \mathrm{~g})$ (Table 4). Average flavonoids content was $8.60 \mathrm{~g} / 100 \mathrm{~g}$ of rhizome pulp.

\subsubsection{Product Developement from Ginger}

Two products were developed from ginger. From each product three treatments were formulated for this investigation. The quality of products was analysing the fowling parameters.

\subsubsection{Colour of Pakora}

There was a significant variation among the 3 treatment in respect of colour of pakora (Table 5). The most attractive colour of pakora(4.00) was found in treatment No. 1 followed by treatment No. 3 (2.00). The least attractive colour of pakora (1.33) was found in treatment No. 2 (Table 5).

\subsubsection{Tasste of Pakora}

The taste of pakora showed significant variation among the 3 treatment (Table 5). The most agreeable taste (3.33) was found in treatment No. 1. The minimum agreeable taste (2.68) was recorded from treatment No. 3 (Table 5).

\subsubsection{Flavour of Pakora}

The difference of flavour was significant among the 3 treatment (Table 5). The highest agreeable flavour of pakora (3.68) was found in treatment No. 2 which was statistically similar to treatment No. 1 (3.33). The least agreeable of flavour of pakora (1.00) was observed from treatment No. 3 (Table 5).

\subsubsection{Crispiness of Pakora}

Significant variation was observed among the 3 treatment in respect of crispiness of pakora (Table 5). Thecrispiestpakora(4.00) was foundin treatment No. 3. Whereas, treatment No. 2 showed the lesscrispy pakora (2.33) (Table 5).

In respect of overall consideration of colour, taste, flavour and texture of pakora treatment No. 2 (6.38) showed better performance among the 3 treatment (Table 5).

Table 5. Taste evaluation of ginger pakore

\begin{tabular}{|l|l|l|l|l|}
\hline Treatment & Colour & Taste & Flavour & Crispiness \\
\hline $\mathrm{T}_{1}$ & $4.00 \mathrm{a}$ & 3.33 & $3.33 \mathrm{a}$ & 3.68 \\
\hline $\mathrm{T}_{2}$ & $1.33 \mathrm{~b}$ & 3.00 & $3.68 \mathrm{a}$ & 2.33 \\
\hline $\mathrm{T}_{3}$ & $2.00 \mathrm{ab}$ & 2.68 & $1.00 \mathrm{~b}$ & 4.00 \\
\hline L.S. & $* *$ & NS & $* *$ & NS \\
\hline
\end{tabular}

In a column figures having similar letters do not differ significantly whereas figures having dissimilar letters differ significantly as per DMRT.

L.S.: Level ofsignificance, ${ }^{* *}$ Significant at $1 \%$ level, NS: Non-Significant

Note:

$\mathrm{T}_{1}=500 \mathrm{~g}$ pulp of ginger and $15 \mathrm{~g}$ flour, $\mathrm{T}_{2}=500 \mathrm{~g}$ pulp of ginger $\mathrm{c}$ and $20 \mathrm{~g}$ flour and $\mathrm{T}_{3}=500 \mathrm{~g}$ pulp of ginger and $25 \mathrm{~g}$ flour

The amounts of other used ingredients to formulate ginger pakora were same for three treatments.

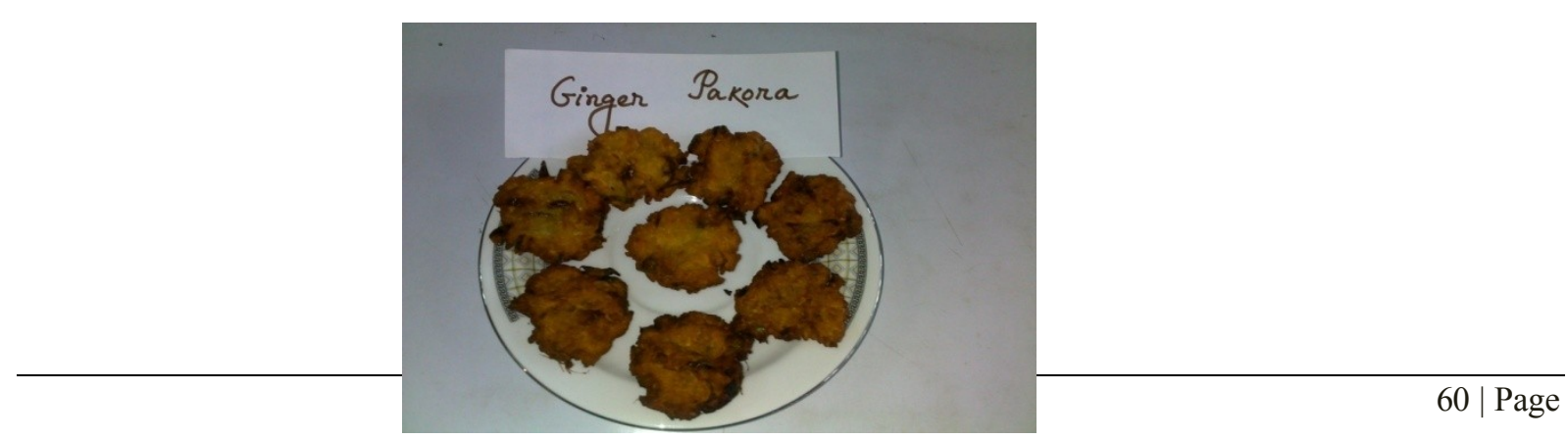




\title{
3.3.2.1Ginger Sauce
}

\author{
Plate 1.Ginger pakora $\left(T_{2}\right)$
}

\subsection{Colour of Sauce}

There was a significant variation among the 3 treatment in respect of colour of ginger sauce (Table 6). The most attractive colour of sauce (3.68) was found in treatment No. 1, which was statistically similar to treatment No. 3 (3.68). The least attractive colour of sauce (2.33) was found in treatment No. 2 (Table 6).

\subsection{Taste of Sauce}

The taste showed significant variation among the 3 treatment (Table 6). The most suitable of taste (4.68) was found in treatment No.1. The least agreeable taste (3.33) was recorded from treatment No. 2 (Table 6).

\subsection{Flavour of Sauce}

The difference of flavour was significant among the 3 treatment (Table 6).The highest agreeable flavour of sauce (4.33) was found in treatment No. 1, followed by treatment No.3 (2.68). The least agreeable flavour of sauce (1.33) was observed from treatment No. 2(Table 6).

\subsection{Texture of Sauce}

The taste showed significant variation among the 3 treatment (Table 6). The thicker of texture(2.68)was found in treatment No. 3 .The thinner texture (1.33) was recorded from treatment No.1 which was statistically similar to treatment No.2 (1.33) (Table 6).

In respect of overall consideration of colour, taste, flavour and texture of sauce treatment No. 2 (6.30) showed better performance among the 3 treatment (Table 6).

Table 6. Taste evaluation of ginger sauce

\begin{tabular}{|c|c|c|c|c|}
\hline Treatment & Colour & Taste & Flavour & Texture \\
\hline $\mathrm{T}_{1}$ & $3.68 \mathrm{a}$ & $4.68 \mathrm{a}$ & $4.33 \mathrm{a}$ & $1.33 \mathrm{~b}$ \\
\hline $\mathrm{T}_{2}$ & $2.33 \mathrm{~b}$ & $3.33 \mathrm{a}$ & $1.33 \mathrm{~b}$ & $1.33 \mathrm{~b}$ \\
\hline $\mathrm{T}_{3}$ & $3.68 \mathrm{a}$ & $4.33 \mathrm{a}$ & $2.68 \mathrm{ab}$ & $2.68 \mathrm{a}$ \\
\hline L.S. & $*$ & N.S. & $* *$ & $*$ \\
\hline
\end{tabular}

In a column figures having similar letters do not differ significantly whereas figures havingdissimilar letters differ significantly as per DMRT.

L.S.: Level ofsignificance, ${ }^{* *}$ Significant at $1 \%$ level, ${ }^{*}$ Significant at $5 \%$ level, NS: Non-Significant

Note: $\mathrm{T}_{1}=500 \mathrm{~g}$ pulp of ginger and $300 \mathrm{~g}$ sugar, $\mathrm{T}_{2}=500 \mathrm{~g}$ pulp of ginger and $400 \mathrm{~g}$ sugar and $\mathrm{T}_{3}=500 \mathrm{~g}$ pulp of ginger $\mathrm{c}$ and $500 \mathrm{~g}$ sugar

The amounts of other used ingredients to formulate ginger sauce were same for three treatments.

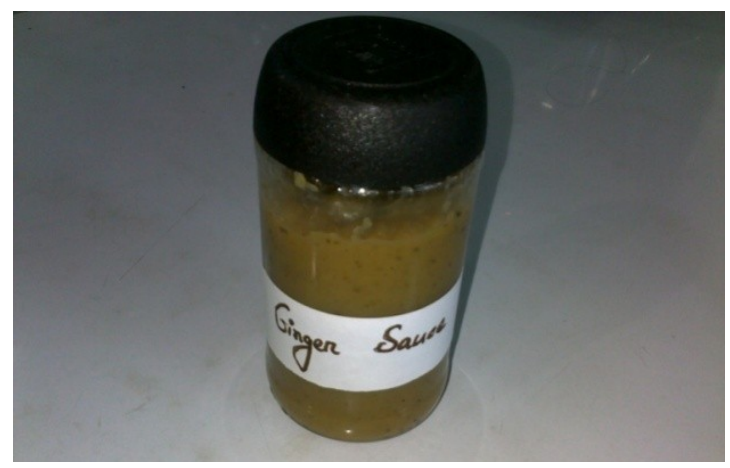

Plate 2. Ginger sauce $\left(\mathrm{T}_{2}\right)$

\section{Conclusion}

The criteria for the selection of the ginger germplasms may be, rhizome weight, weight of pulp, weight of skin, length of rhizome, width of rhizome, height of rhizome, pulp thickness and skin thickness of rhizome, Vitamin C, Total soluble solid (TSS), $\mathrm{pH}$ and titratable acidity, carotinoids, anthocyanine and flavonoids of rhizome pulp. Most of the characters of ginger were found superior in germplasm No. 01, 02, 07 and 06. Further trial is needed on other characters of the germplasm like reducing sugar, non-reducing sugar, phenol, antioxidant 
etc. for the selection of the above mentioned germplasm as variety. If the product of ginger increases it will help to fulfill the rhizome demand and reduce malnutrition problem of rural people of the country.

\section{References}

[1] Ahmed, R. and S. Sharma, Biochemical studies on combined effect of garlic (Allium sativum L.) and ginger (Zingiber officinalis) in albino rats. Indian Journal of Experimental Biology, 3(5), 1997: 841-843.

[2] American Spice Trade Association (ASTA), A concise guide to Spices, Herbs, Seeds, and Extractives. (Magra-Hill Pub. Co. Ltd., New York, 2002) 51.

[3] O.I. Aruoma, J.P. Spencer, D. Warren, P. Jenner, J. Butler and B. Halliwell, Characterization of food antioxidants, illustrated using commercial garlic and ginger preparations. Food Chemistry, 6,1997: 49-156.

[4] L. B. Barker, How does ginger grow? Web (URL) address: http://www.ehow.com/how does_4566992_ginger-grow.html, 2010, Accessed on March 2013.

[5] J. Bartley and A. Jacobs, Effects of drying on flavour compounds in Australian-grown ginger (Zingiber officinalis). Journal of Science and Food Agriculture 80(2),2000: 209-215

[6] B.B. Bradtke, How to grow ginger. Web (URL) address: http://www.tropicalpermaculture.com/growing-ginger.html, 2010, Accessed on May 2013.

[7] J.D. Drori, Plant cultures ginger. Web (URL) address http://www.plant cultures. org/ plants / ginger_plant_profile. html, 2005, Accessed on January, 2013.

[8] S.F. Foster, (2010). Web (URL) address: http://www.stevenfoster.com/company/steven/index.html, 2010, Accessed on December 2012.

[9] R. Grzanna, L. Lindmark and C. Frondoza, Ginger-A herbal medicinal product with broad anti-inflammatory actions. Journal of . Medicine and Food, 8(2),2005: 125-132.

[10] M. M. Hossain and M. A. Siddique, Taste and Visual Acceptibility of Some Exotic and Local Cultivars of Sweet Potato. Pakistan Journal of Scientific Research, 34 (34), 1982: 113-119.

[11] M.K. Kelly, The life cycle of ginger plant. Web (URL) address: http://www.ehow.com/facts_6053439_life-cycle-gingerplants.html, 2010,Accessed on February 2013.

[12] J. Kizhakkayil and B. Sasikumar, Diversity. Characterization and utilization of ginger: a review. Plant Genetic Research: Characterization and Utilization, 9 (1), 2011: 464-477.

[13] L. L. Lambson, Ginger Tea. Web (URL) address:http://www.brighthub.com/ health/alternative-medicine /articles/18698.aspx, 2010, Accessed on May 2013.

[14] B. C. Mazumder and K. Majumder, Methods on physico- chemical analysis of fruits, 2003: 1-162.

[15] G. Murillo, R. Naithani and R.G. Mehta, Efficacy of Herbal Products in Colorectal Cancer Prevention. Current Colorectal Cancer Reports, 4, 2008: 34-42.

[16] A. Nievergelt, P. Huonker, R. Schoop, K.H. Altmann and J. Gertsch, Identification of serotonin 5-HT1A receptor partial agonists in ginger. Bioorganic \& Medicinal Chemistry. 18(9), 2010: 3345-3351.

[17] S. Ranaganna, Lab Manual Analysis of Fruits and Vegetables products. (Tata McGraw Hill Publishng Company Ltd., New Delhi, 1979)140-144.

[18] R. S. Saini, K. D. Sharma, O. P. Dhankhar and R. A. Kaushik, Laboratory Manual of Analytical Techniques in Horticulture. Dr. UpdeshProhit for Agrobios (India), 2006: 5-112.

[19] B. Sasikumar, K.V. Saji, P.N. Ravindran and K.V. Peter, Genetic resources of ginger (Zingiber officinalis) and its conservation in India, 1999:13-28

[20] D.S. Schar, Planet biotanic ginger. Web (URL) address: http://www.planetbotanic. ca/fact_sheets/ginger_fs.htm, 2006, Accessed on January 2013.

[21] J.S. Scheper, Zingiber officinalis. Floridata plant encyclopedia.Web (URL) address: http://www.floridata.com/ref/z/zing_off.cfm, 2010, Accessed on January 2013.

[22] W.S. Sidhe, Ginger root facts. Web (URL) address: http:// www.ehow. Com /about_5349862_ginger-root.html, 2010, Accessed on February 2013.

[23] G. Singh, I.P. Kapoor, S. P. ingh. C. S. Heluani, M.P Lampasona and C.A. Catalan, Chemistry, antioxidant and antimicrobial investigations on essential oil and oleoresins of Zingiber officinalis. Food Chemistry Toxicology, 4(6), 2008: 3295-302.

[24] Y. J. Surh, E. Lee and J.M. Lee, Chemopreventive properties of some pungent ingredients present in red pepper and ginger. Mutation Research, 4(2), 1998: 259-267.

[25] B. Tepe, M. Sokmen, H.A. Akpulat and A. Sokmen, Screening of the antioxidant potentials of six Salvia species from Turkey. Food Chemistry, 9(5), 2006: 200-204.

[26] Q. Y Wei, J.P. Ma, Y.J. Cai, D.Yang and Z.L. Liu, Cytotoxic and apoptotic activities of diarylheptanoids and gingerol-related compounds from the rhizome of Chinese ginger. Journal of Ethnopharmacy, 10(2), 2005: 177-184. 